\title{
Carbon Stock of Indigenous Agroforestry Practices in Dellomenna District Southeast Ethiopia: Implication for Climate Change Mitigation
}

\author{
Abiot Molla $^{1} \quad$ Gonfa Kewessa ${ }^{2}$ \\ 1.Department of Natural Resource Management, Debremarkos University, Debremarkos, ETHIOPIA \\ 2.Department of Forestry, Ambo University, P.O. Box 19, Ambo, ETHIOPIA
}

\begin{abstract}
Trees in agroforestry systems are potential sinks of atmospheric carbon (C) due to their fast growth, productivity, high and long-term biomass $\mathrm{C}$ stock. Soil under forest and agroforestry also plays a major role in global $\mathrm{C}$ sequestration. This study was initiated to assess woody species and soil $\mathrm{C}$ sequestration of traditional agroforestry practices. Three study sites (namely: Buriketu, Chire and Erba) were systematically selected based on the presence of traditional agroforestry practices. Forty eight sample quadrats (16 quadrats in each site) having an area of $20 \mathrm{~m} \times 20 \mathrm{~m}\left(400 \mathrm{~m}^{2}\right)$ were used for vegetation biomass estimation. Soil organic carbon (SOC) was sampled by using " $\mathrm{X}$ " design at depths of $0-30 \mathrm{~cm}$ within each quadrats. Woody species biomass carbon stocks were estimated using an allometry equation of $\mathrm{Y}(\mathrm{Kg})=34.4703-8.0671 \mathrm{DBH}+0.6589 \mathrm{DBH}^{2}$. $\mathrm{The}^{-}$ types of agroforestry practices found in the study area are scattered trees in farm lands (parkland agroforestry), homegarden and live fence system. The mean AGBC stock showed an increasing trend from $\mathrm{DBH} \geq 5 \mathrm{~cm}$ to 71 $\mathrm{cm}$ while a decreasing trend was noticed greater than $71 \mathrm{~cm}$ diameter classes. The mean carbon stocks (Means \pm Std) of different carbon pools in the indigenous agroforestry practice were $47.82 \pm 10.09,11.96 \pm 2.52$, $59.77 \pm 12.61,150.61 \pm 6.9,210.39 \pm 14.1$ for AGBC stock, BGBC stock, TBC stock, SOC and TCSD, respectively. $\mathrm{CO}_{2}$ assimilation by total biomass of woody species $\geq 5 \mathrm{~cm}$ DBH in traditional agroforestry practices was estimated to be $219.15 \mathrm{ton} / \mathrm{ha}$. Estimation of $\mathrm{CO}_{2}$ sequestration indicated that indigenous agroforestry practices of the area have been sequestered (772.02 ton/ha). The results of the present study confirmed that indigenous agroforestry practice play a major role in climate change mitigation. This study was focused on the biomass carbon stock of woody species $\geq 5 \mathrm{~cm} \mathrm{DBH}$, however, woody species $<5 \mathrm{~cm} \mathrm{DBH}$, dead wood, dead standing trees, fallen branches and litter-fine woody debris were also have a potential for $\mathrm{C}$ stock, thus further study on these components is recommended to provide reliable information.
\end{abstract}

Keywords Biomass carbon, Ecosystem services, Global warming, Soil organic carbon.

DOI: $10.7176 / \mathrm{JEES} / 9-5-03$

Publication date:May $31^{\text {st }} 2019$

\section{Introduction}

Agroforestry land use system provides various ecosystem services. Some of the benefits are diversification of household income, fiber, food and energy to local communities and also provides cultural services such as agrotourism, aesthetic values and education (Negash 2013). Agroforestry also provides regulating services such as soil conservation, watershed protection, pest control and sinks for carbon and thereby contributing to the mitigation of global climate change (IPCC 2000; Albrecht and Kandji 2003). However, long history of sedentary agriculture leads to climate change through the increasing of $\mathrm{CO}_{2}$ and other greenhouse gases and biodiversity losses (Bishaw and Asfaw 2010). According to Montagnini and Nair (2004), tree components of agroforestry systems are one of the options to sink atmospheric $\mathrm{C}$ due to their fast growth and productivity, high and longterm biomass carbon stock, and extensive root system. The $\mathrm{C}$ storage potential of agroforestry systems in semiarid, sub-humid, humid and temperate regions has been estimated to be 9, 21, 50 and $63 \mathrm{Mg} \mathrm{C}^{-1}$, respectively (Montagnini and Nair 2004). The potential of above ground C stock of agroforestry systems in

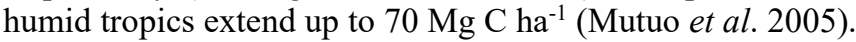

Soil ecosystem of agroforestry land use system also plays a major role in global C sequestration (Lal 2002). The term "soil $\mathrm{C}$ sequestration" implies removal of atmospheric $\mathrm{CO}_{2}$ by plants and storage of fixed $\mathrm{C}$ as soil organic matter. SOC is recognized as a strategy for $\mathrm{C}$ sequestration under the Clean Development Mechanisms of the Kyoto Protocol (Nair et al. 2009b). For instance, the soil under cocoa agroforestry store $37 \mathrm{Mg} \mathrm{C} \mathrm{ha}^{-1}$ in the Southern Cameroon (Sonwa et al. 2009).

Despite of various benefits of agroforestry, little scientific studies has been paid to the role of agroforestry systems in climate change mitigation (Kumar and Nair 2004; McNeely and Schroth 2006). Most studies on agroforestry systems in the tropics including Ethiopia have been focused on socio-economic and soil fertility management. The areas of agroforestry systems in Ethiopia is not well documented, but some $2.32 \mathrm{Mg} \mathrm{ha}^{-1}$ are considered as agroforestry land use according to some estimates based on satellite image (Brown et al. 2012). Some of the traditional agroforestry practices in the country include coffee shade tree systems, scattered trees on 
the farm land, homegardens, woodlots, farm boundary practices and trees on grazing lands (Asfaw 2003; Abebe 2005).

In Dellomenna District (the study area), farmers have been practicing integration of trees, crops and livestock components in their lands. These indigenous agroforestry practices constitute perennial and herbaceous plants that can promote biodiversity conservation, climate change mitigation, and socioeconomic alternatives to the local communities. Indeed, the contribution of this indigenous agroforestry practice on $\mathrm{C}$ stock has not been studied. Therefore, this study was initiated to investigate extent of woody species and soil carbon stocks in indigenous agroforestry practices with particular emphasis on their contribution to climate change mitigation.

\section{Materials and Methods}

\subsection{The study area}

Dellomenna District is situated between $6040^{`}$ to 7010 `N latitude and 39030 to 400 E longitude. The altitude of the district ranges between 1000 - 2500 meter above sea level. Mean annual rainfall in the area varies from around $700 \mathrm{~mm}$ to $1200 \mathrm{~mm}$ and temperature is $18^{\circ} \mathrm{C}$ (Feyera 2006). The total area of the district is 461,665 hectares (Feyera 2006). The major land use categories of the district are forest land, agriculture, grazing land, and settlement (Feyera 2006). Natural forest and wood lands still accounts the largest share of the land use types in the district. Worku (2011) also indicated that homegarden, multipurpose trees on the farm land and farm boundary, agrosilvopastural, apiculture with trees and silvopasture are some of the example of agroforestry practices in the area.

\subsection{Data Collection Methods}

\subsubsection{Sampling techniques}

Systematic sampling techniques were employed on the basis of potential indigenous agroforestry practices of the area. Accordingly three kebeles (namely: Buriketu, Chire and Erba) were selected. Based on the topography, four transect lines were aliened at interval of $500 \mathrm{~m}$ between transect lines in each Kebele. On each transect, four quadrats was laid at an interval of $200 \mathrm{~m}$. The first transect line and quadrant was selected by systematic random sampling. A total of 48 quadrats (16 quadrats in each Kebele) were used for carbon stock assessments.

\subsubsection{Sampling design}

A quadrat size of $20 \mathrm{~m} \times 20 \mathrm{~m}\left(400 \mathrm{~m}^{2}\right)$ was used for all woody plants assessment for diameter $\geq 5 \mathrm{~cm}$ as described in Hernandez et al. (2004). Within $20 \mathrm{~m} \times 20 \mathrm{~m}$, four sub-quadrants of $5 \mathrm{~m} \times 5 \mathrm{~m}$ at the corners and one in the center were laid for coffee biomass assessment. The diameter of woody species at breast height (DBH1.3m) was measured using a caliper or diameter tape (MacDiken 1997).

Soil organic carbon was sampled by using " $X$ " design with a depth of 0-30 cm (Figure 1). That is, soils from four corners and at the center were mixed to make representative composite soil sample in each quadrat. Forty eight (48) composite soil samples were used for organic carbon determination. For bulk density, soil sample near to the center of the quadrant was taken using $4.3 \mathrm{~cm}$ length and $3 \mathrm{~cm}$ diameter core sampler.
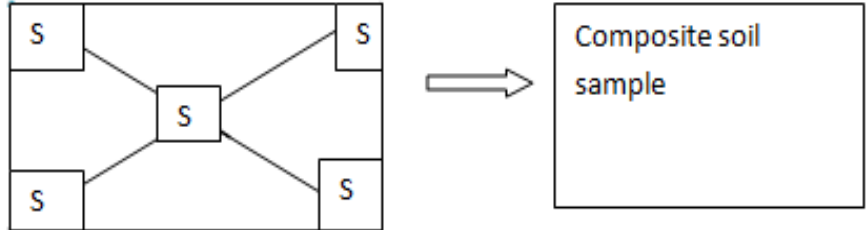

Figure 1. Diagrammatic representation of soil sampling design, $\mathrm{S}$ - stands for soil

\subsubsection{Estimation of Above ground biomass (AGB) carbon stock}

$$
\text { Source: Adapted from (IPCC 1997) }
$$

According to Brown and Schroeder (1999), the use of species-specific regression models is difficult; hence, mixed and non-destructive species tree biomass regression models were used for estimation of AGB. The best estimator of this study was selected based on rainfall distribution, diameter range, prediction errors, $\mathrm{R}^{2}$, simplicity of the models and sample size. The present study area is close to moist kola type of agro-ecology. Thus, the following regression models that can be applicable in moist kola were selected (Table 1).

Table 1. The allometeric model for estimating of AGB C stock in the study area

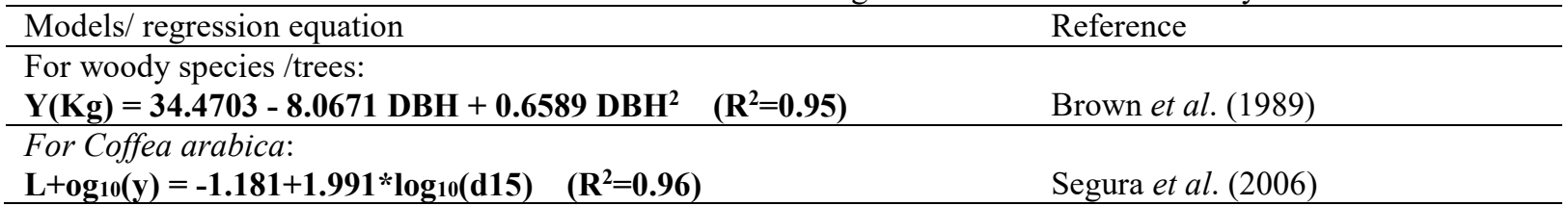




\subsection{Data analysis}

Carbon stock (CS) were converted in the form of $\mathrm{CO}_{2}$ equivalent (ton $\mathrm{CO}_{2}$ equivalent ha' ${ }^{-1}$ ) $=\mathrm{CS}(\mathrm{t}) * 44 / 12$ as described in Getu et al. (2011). Where $\mathrm{CS}=$ the mean Carbon stock in ton ha ${ }^{-1}$ at time of $(\mathrm{t}), 44 / 12=$ Ratio of molecular weight of $\mathrm{CO}_{2}$ to carbon (44= the molecular weight of $\mathrm{CO}_{2}$ and $12=$ the molecular weight of carbon).

Cairns et al. (1997) and Roshetko et al. (2002) indicated that below ground biomass (BGB) of woody species were estimated from root-shoot ratios $(\mathrm{R} / \mathrm{S})$ by taking $25 \%$ of AGB. The $\mathrm{C}$ content of AGB and BGB was assumed as 50\% of the estimated whole-tree biomass (Mac Dicken 1997; Nair et al. 2011).

SOC was determined using Walkley-Black method (Walkley and Black 1934). The soil samples for soil carbon analysis were air-dried and passed through a $2 \mathrm{~mm}$ sieve. Soil bulk density was also determined by dividing oven dried weight of the soil samples at $105^{\circ} \mathrm{C}$ for 24 hours to the volume of the core sampler. The soil carbon stock in hectare based was calculated as described in Lemma (2006); i.e., SOC $\left.\left(\mathrm{Mg} \mathrm{ha}^{-1}\right)=\mathrm{SOC}^{-3} \mathrm{gg}^{-1}\right)$ $\mathrm{x} \mathrm{d} \mathrm{x} \mathrm{BD}\left(\mathrm{Mg} \mathrm{m}^{-3}\right) \times 10$, Where $\mathrm{d}=$ sampled soil depth in meter $(\mathrm{m})$, and $\mathrm{BD}=$ bulk density $\left(\mathrm{Mg} \mathrm{m}^{-3}\right)$. The total carbon stock density (TCSD) was the summation of AGB, root biomass and soil carbon stocks. Finally, the variation in carbon stocks was tested using one way ANOVA. Means exhibited significance difference was tested by Least Significance Difference (LSD) at $\mathrm{p}<0.05$ using SAS version 9.0.

\section{Results and Discussions}

\subsection{Indigenous agroforestry practice}

The types of agroforestry practices found in the study area are scattered trees in farm lands (parkland agroforestry), homegardens and live fence system. Trees dominated in the indigenous agroforestry practice are fruit trees and trees for live fence.

\subsection{Carbon stock pools}

\subsubsection{Aboveground biomass (AGB)}

The mean aboveground biomass $\mathrm{C}$ stock showed an increasing trend from $\mathrm{DBH} \geq 5 \mathrm{~cm}$ to $71 \mathrm{~cm}$ while a decreasing trend was noticed greater than $71 \mathrm{~cm}$ diameter classes (Figure 2).

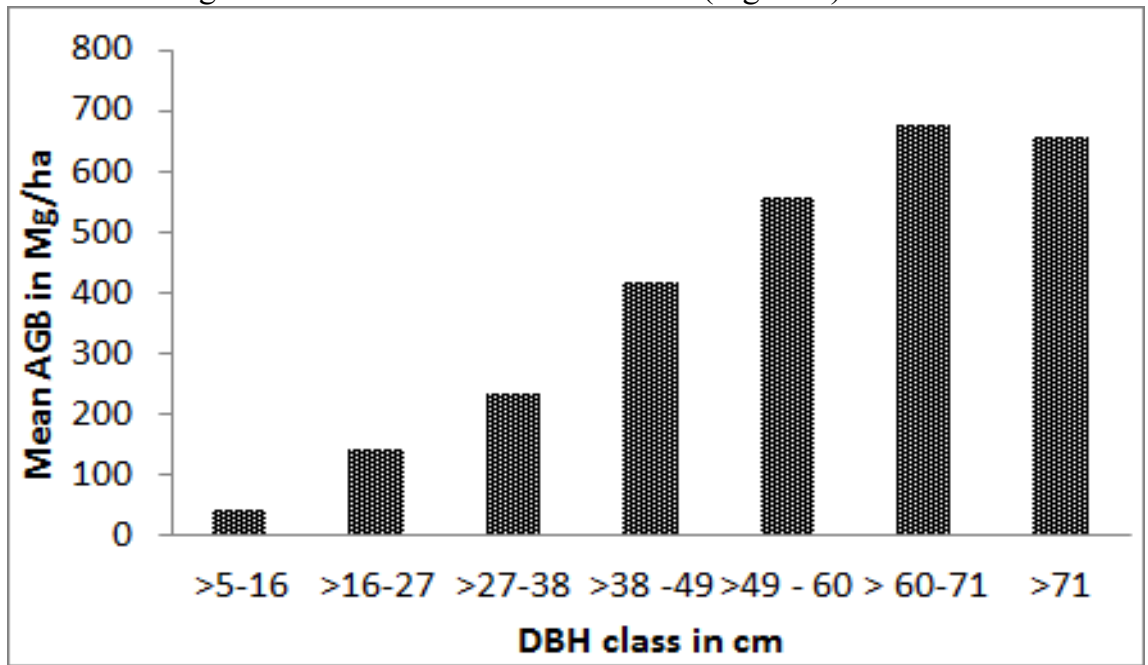

Figure 2. The average AGB distribution of different woody species in diameter classes

The greater contribution of large trees to AGB in study sites were in conformity with the findings of other scholars (Brown et al. 1995; Brown 1996; Clark and Clark 1996) who reported up to 50\% contribution to AGB by the large trees. However, the trees have marginal carbon sequestration capability (Lal and Singh 2000). This could be due to the matured forests do not add up any further biomass and most part of the gross primary productivity is either used up in respiration or returned to soil as litter.

\subsubsection{Total carbon stock density}

The total means carbon stock density (TCSD) which includes the AGBC stock, BGBC stock and SOC stock, was presented in Table 2 . 
Table 2. Mean carbon stocks of different carbon pools in the traditional agroforestry practice of the study area

\begin{tabular}{l|ccccc}
\hline & \multicolumn{6}{|c}{ Different carbon pools Mg ha ${ }^{-1}$} & & & \\
\hline \multirow{2}{*}{ Kebeles/ sites } & AGBC stock & BGRBC stock & TBC stock & SOC & TCSD \\
\cline { 2 - 6 } & Means $( \pm$ Std $)$ & Means $( \pm$ Std $)$ & Means $( \pm$ Std $)$ & Means $( \pm$ Std $)$ & Means $( \pm$ Std $)$ \\
\hline Buriketu & $86.99 \pm 26.04$ & $21.75 \pm 6.51$ & $108.73 \pm 32.4$ & $162.66 \pm 15$ & $271.39 \pm 38$ \\
Erba & $25.55 \pm 8.37$ & $6.39 \pm 2.09$ & $31.94 \pm 10.46$ & $136.67 \pm 9.4$ & $168.61 \pm 18$ \\
Chire & $30.93 \pm 7.44$ & $7.73 \pm 1.86$ & $38.66 \pm 9.31$ & $152.49 \pm 14$ & $191.16 \pm 19$ \\
\hline Overall mean & $\mathbf{4 7 . 8 2} \pm \mathbf{1 0 . 0 9}$ & $\mathbf{1 1 . 9 6} \pm \mathbf{2 . 5 2}$ & $\mathbf{5 9 . 7 7} \pm \mathbf{1 2 . 6 1}$ & $\mathbf{1 5 0 . 6 1} \pm 6.9$ & $\mathbf{2 1 0 . 3 9} \pm 14.1$ \\
\hline
\end{tabular}

In the study area, the total biomass (above and below ground) values for various indigenous agroforestry practice range from $31.94-108.73 \mathrm{Mg} \mathrm{ha}^{-1}$. This result agrees with the study of indigenous agroforestry systems which ranges from 105-173 $\mathrm{Mg} \mathrm{ha}^{-1}$ in Gedeo Zone, Southern Ethiopia (Negash 2013). It is in line with the findings of others scholars elsewhere (Dixon 1995; Albrecht and Kandji 2003) that ranges from 12-228 $\mathrm{Mg} \mathrm{C}^{-}$ ${ }^{1}$, but higher than the range reported for agroforestry systems in sub-Saharan Africa (4.5-19 $\mathrm{Mg} \mathrm{C} \mathrm{ha}^{-1}$ ) (Unruh et al. 1993).

The mean SOC stock of indigenous agroforestry systems in the study area was found to be $150.61 \mathrm{Mg} \mathrm{ha}^{-1}$. In line with the present study, SOC stocks of 115-122 $\mathrm{Mg} \mathrm{ha}^{-1}$ was reported by Negash (2013). Batjes (1996) also indicated SOC stocks of $41 \mathrm{Mg} \mathrm{ha}^{-1}$ for 0-30 $\mathrm{cm}$ soil depth.

\subsection{Carbon stock pools in carbon dioxide equivalent $\left(\mathrm{CO}_{2}-e\right)$}

The different carbon pools (AGBC, BGRC, TBC and SOC) and TCSD in carbon dioxide equivalent in the study area was presented in Figure 3.

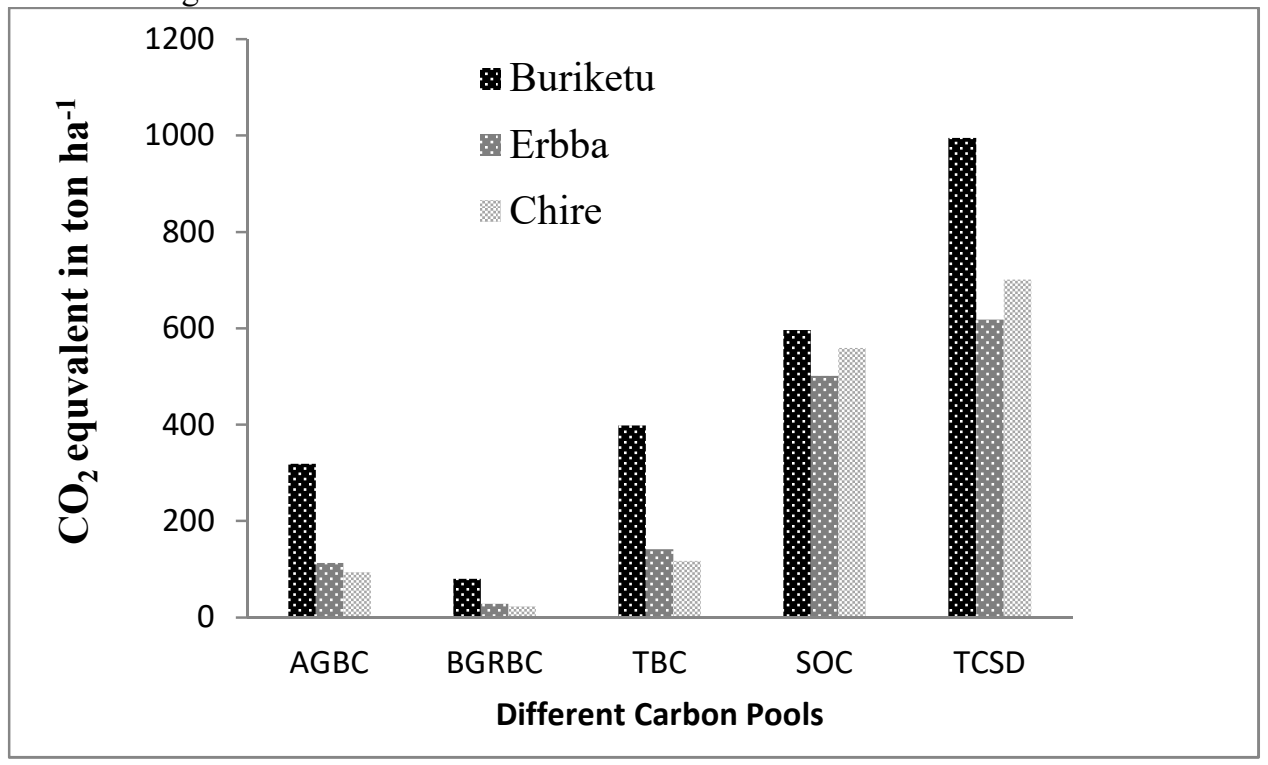

Figure 3. Carbon stock pools in carbon dioxide equivalent across study Kebele

$\mathrm{CO}_{2}$ assimilation by aboveground and belowground biomass of woody species $\geq 5 \mathrm{~cm}$ DBH in indigenous agroforestry practices was estimated to be 175.34 and 43.85 ton/ha, respectively. Similarly, $\mathrm{CO}_{2}$ assimilation by total biomass of woody species $\geq 5 \mathrm{~cm}$ DBH in traditional agroforestry practices was estimated to be 219.15 ton $\mathrm{ha}^{-1}$. Murthy et al. (2013) indicated that agroforestry provides a unique opportunity to combine the twin objectives of climate change adaptation and mitigation. It has the ability to enhance the resilience of the system for coping with the adverse impacts of climate change.

\section{Conclusion and Recommendations}

The types of agroforestry practices found in the study area are scattered trees in farm lands (parkland agroforestry), homegarden and live fence system. Trees dominated in the indigenous agroforestry practice are fruit trees like Mangefira indica and trees for live fence. The mean AGBC stock showed an increasing trend from $\mathrm{DBH} \geq 5 \mathrm{~cm}$ to $71 \mathrm{~cm}$ while a decreasing trend was noticed greater than $71 \mathrm{~cm}$ diameter classes. The mean carbon stocks (Means \pm Std) of different carbon pools in the indigenous agroforestry practice were 47.82 \pm 10.09 , $11.96 \pm 2.52,59.77 \pm 12.61,150.61 \pm 6.9,210.39 \pm 14.1$ for AGBC stock, BGBC stock, TBC stock, SOC and TCSD, respectively. $\mathrm{CO}_{2}$ assimilation by total biomass of woody species $\geq 5 \mathrm{~cm} \mathrm{DBH}$ in traditional agroforestry practices was estimated to be 219.15 ton/ha. Estimation of $\mathrm{CO}_{2}$ sequestration indicated that indigenous agroforestry practices of the area have been sequestered (772.02 ton/ha). This study was focused on the biomass 
carbon stock of woody species $\geq 5 \mathrm{~cm} \mathrm{DBH}$, however, woody species $<5 \mathrm{~cm} \mathrm{DBH}$, dead wood, dead standing trees, fallen branches and litter-fine woody debris were also have a potential for $\mathrm{C}$ stock, thus further study on these components is recommended to provide reliable information.

\section{ACKNOWLEDGEMENT}

The authors thank Madda Walabu University for providing financial support for the research work. Authors would also like to express their cordial thank you to Dellomena District Pastoral Development Office of Bale Zone. Development agents of the study sites were highly acknowledged for their cooperation. Moreover, farmers who opened the gates of their farm land as well as those people who provided their supports directly or indirectly for the successful accomplishment of this research also acknowledged. Hawassa University Wondo Genet College of Forestry and Natural Resources Soil Testing laboratory workers were also acknowledged for their cooperation in preparation and soil data analysis.

\section{Conflict of interest}

The authors declare that they have no conflict of interest.

\section{REFERENCES}

Abebe T (2005). Diversity in homegarden agroforestry systems in Southern Ethiopia. dissertation. Wageningen University, Wageningen. ISBN 90-8504-163-5. Pp77-90.

Albrecht A, Serigne T, Kandji (2003). Carbon sequestration in tropical agroforestry systems. Institute research Development (IRD), International Centre for Research in Agroforestry (ICRAF). Agric, Ecosy and Envirn 99: $15-27$.

Asfaw Z (2003). Tree Species Diversity, Top Soil Conditions and Arbuscular Mycorrhizal Association in the Sidama Traditional Agroforestry Land-Use, Southern Ethiopia. Dissertation. Swedish University of Agriculture, Uppsala, Sweden. 263pp.

Batjes NH (1996). Total carbon and nitrogen in the soils of the world. Europe J. Soil Sci. 47:151-163.

Bishaw B, Asfaw Z ( 2010). Water resources management in Ethiopia: implications for the Nile Basin, hydrological and related aspects of deforestation and degradation of woody vegetation. Cambria press, Amherst, New York. Pp183-202.

Brown IF, LA, Martinelli WW, Thomas MZ, Moreira, CAC, Ferreira RA (1995). Uncertainty in the biomass of Amazonian forests - an example from Rondonia, Brazil. Fore. Ecol Manage. 75: 175-189.

Brown S (1996). Tropical forests and the global carbon cycle: estimating state and change in biomass density, Forest Ecosystems, Forest Management and the Global Carbon Cycle. NATO ASI Series, Springer-Verlag. pp. 135-144.

Brown S, Gillespie AJR, Lugo AE (1989). Biomass estimation methods for tropical forests with applications to forest inventory data. Fore. Sci.35: 881-902.

Brown S, Grais A, Ambagis S, Pearson T (2012) . Baseline GHG emissions from the agricultural sector and mitigation potential in countries of East and West Africa. CCAFS Working paper no. 13. CGIAR research program on climate change, agriculture and food security (CCAFS). Copenhagen, Denmark. Available online at: www.ccafs.cgiar.org.

Brown S, Schroeder PE (1999). Spatial patterns of aboveground production and mortality of woody biomass for eastern US forests. Ecolo. Appli. 9: 968-980.

Cairns, M.A, Brown, S., Helmer, E.H., \& Baumgardner, G.A. 1997. Root biomass allocation in the world's upland forests. Oeclogia 111(1): 1-11.

Clark DB, Clark DA (1996). Abundance, growth, and mortality of very large trees in geotropically lowland rain forest. Forest Ecology and Management 80: 235-244. allocation in the world's upland forests. Oeclogia 111(1): 1-11.

Dixon RK (1995). Agroforestry systems: sources or sinks of greenhouse gases? Agroforestry Systems 31:99-116.

Feyera S (2006). Biodiversity and ecology of Afromontane rainforest with wild Coffee arabica L. populations in Ethiopia. Ecology and development series No. 38

Getu Z, Dale G, Tafa M, James G, Njogu, Gonfa T (2011). Carbon Stock Assessment in Different Land Uses for REDD+ in Ethiopia. Practitioners Field Guide/Manual. Yayu Forest Coffee Biosphere Reserve. 33pp.

Hernandez RP, Koohafkan P, Antoine J (2004). Assessing carbon stocks and modeling win-win scenarios of carbon sequestration through land-use changes. FAO of the United Nations, Rome. Pp 25-120.

IPCC (2000). The intergovernmental panel on climate change: A special report on land-use, and-use change and forestry. Inter-governmental Panel on Climate Change, Cambridge University Press, Cambridge, UK. ISBN 92-9169-119-4. 78pp.

IPCC (1997). Revised 1996 IPCC Guidelines for National Greenhouse Gas Inventories -Workbook (Volume 2). http://www.ipcc.ch. 
Kumar BM, Nair PKR (2004). The enigma of tropical homegardens. Agroforestry Systems 61: 135-152.

Lal R (2002). Soil Carbon dynamics in croplands and rangelands. Environmental Pollution 116: 353- 362.

Lal R, Singh M (2000). Carbon sequestration potential of Indian forests. Environmental Monitoring and Assessment 60: 315-327.

Lemma B (2006). Impact of exotic tree plantations on carbon and nutrient dynamics in abandoned farmland soils of southwestern Ethiopia, Doctor's dissertation. ISBN 91-576-7257-1. 42pp.

Mac Dicken KG (1997). A Guide to Monitoring Carbon Storage in Forestry and Agroforestry Projects. Winrock International, Arlington, Virginia, USA.

McNeely JA, Schroth G (2006). Agroforestry and biodiversity conservation traditional practices, present dynamics, and lessons for the future. Biodiversity and Conservation 15:549-554.

Montagnini F and Nair PKR (2004). Carbon sequestration: An underexploited environmental benefit of agroforestry systems. Agroforestry Systems 61: 281-295.

Murthy IK, Gupta M, Tomar S, Munsi M, Tiwari R (2013). Carbon Sequestration Potential of Agroforestry Systems in India. Journal of Earth Science and Climate Change 4: 131-147.

Mutuo PK, Cadisch G, Albrecht A, Palm CA, Verchot L (2005). Potential of agroforestry for carbon sequestration and mitigation of greenhouse gas emissions from soils in the tropics. Nutrient Cycling in Agro-ecosystem 71:43-54.

Nair P K R, Nair V D, Gama-Rodrigues E F, Garcia R, Haile S G, Howlett DS ,Kumar BM, Mosquera-Losada MR, Saha SK, Takimotog ANG, Tonucci RG (2009b). Soil carbon in agroforestry systems: an unexplored treasure.

Nair PKR, Nair VD, Kumar BM, Showalter JM (2011). Carbon sequestration in agroforestry systems. Opportunities and Challenges, Advance Agronomy 8: 20-35.

Negash M (2013). The indigenous agroforestry systems of the south-eastern Rift Valley escarpment, Ethiopia: Their biodiversity, carbon stocks and litterfall. PhD Dissertation, University of Helsinki, Finland.

Roshetko JM, Delaney M, Hairiah K, Purnomosidhi P (2002). Carbon stocks in Indonesian homegarden systems: can smallholder systems be targeted for increased carbon storage? American Journal of Alternative Agriculture 17:138-148.

Segura M, Kanninen M, Sua'rez D (2006). Allometric models for estimating aboveground biomass of shade trees and coffee bushes grown together. Agroforest System 68:143-150.

Sonwa DJ, Weise SF, Nkongmeneck BA, Tchatat M, Janssens MJJ (2009). Carbon stock in smallholder chocolate forest in Southern Cameroon and potential role in climate change mitigation. IOP Conf. Series: Earth and Environmental Science 6: 125-208.

Unruh JD, Houghton RA, Lefebvre PA (1993). Carbon storage in agroforestry: an estimate for sub-Saharan Africa. Climate Research 3:39-52.

Walkley A, Black IA (1934). An examination of the Degtjareff method for determining soil organic matter and a proposed modification of the chronic acid titration method. Soil Science 37: 29-38.

Worku A (2011). Status of traditional agroforestry and its future Potential development as buffer zone agroforestry for the natural forest conservation in Burkitu Peasant association, Oromia, Ethiopia. MSc. Thesis, of Hawassa University, Wondo Genet College of Forestry and natural resources, Ethiopia. 